\title{
局部電池電位の測定による腐蝕試験
}

\section{訳者伊藤伍 郎*}

\section{Corrosion Testing by Measurement of Local Cell Potentials}

James K. Rice

Corrosion, Vol.10, No.1, 25 29 (1954) January

電解質の稀薄溶液中での金属の腐蝕は, その表面にあ る無数の局部電池の作用によっておこるのが常である。 金属がその単位面積から溶液中へとけこんでゆく量の合 計は，その面積中にあるそれぞれの局部電池から溶液中 へとけこも量を合せたるのに等しい。局部電池作用の状 態は色々であり，またそれは溶液の特性と同時にその電 位の複雑な函数である。そしてまたその局部電池電位は 金属の表面の各点の化学成分, 結晶構造和よび応力等の 函数であう。

これらの局部電池電位や局部電池の電流のためのオー 么電位の測定は，最近までは特別な場合にのみ奏行可能 であった。この測定をはじめて企てた頃に生じた困難な 点は，試験せんとする金属で作った䞟転電極と固定した 探針電極とを組合せて用いることにより克服された。こ の装置と技術について詳しく述べた $2 \sim 3$ の論文が

MIcAndrews, Colner, Francis 1,2) 就よ゙著者 3,4)に より提出されている。

原理

この方法の原理は試験片の表面が，固定した探針電極 に対して循環経路を通って速かに動くことである。そこ で第1図に電気的な比嗡で示したように探針はAーAの

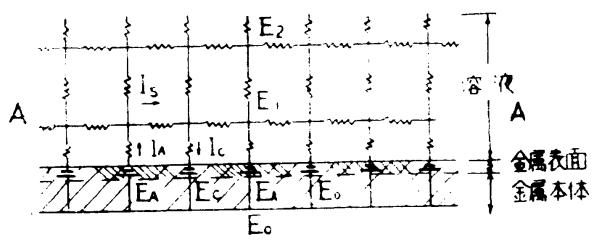

第1図 電解質中で腐飿しつつある金属になぞ らえれ電気回路

道の抵抗に沿つて滑動する接点の作朋をする。この道の 雪位は各点でちがっているのて，探針と試片の表面との 間の相刘渾動のための小さな父流電圧が試片と基準電極 そよりなる電池の大さな直流電压に印加されて生ずる。 探針の動く道を循環させる，さなうらこの場合には探針 它試片の周囲に沿ってまわすことにより，電位も循環的

*利学研究所
に変化する。循環的な電位はオッシロスコープを用いて 求められ，陰極線管の面に定常図形となってあらわれ る。図形の縱軸 ( $y$ 軸) は探針の動いた道 ( $x$ 軸) に沿っ ての試片と基準電極とよりなる電池の電位をあらわす。 この測定に用いた装置を第 2,3 およびに 4 図に示す（第 2 図および第 3 図略す, 訳者)。

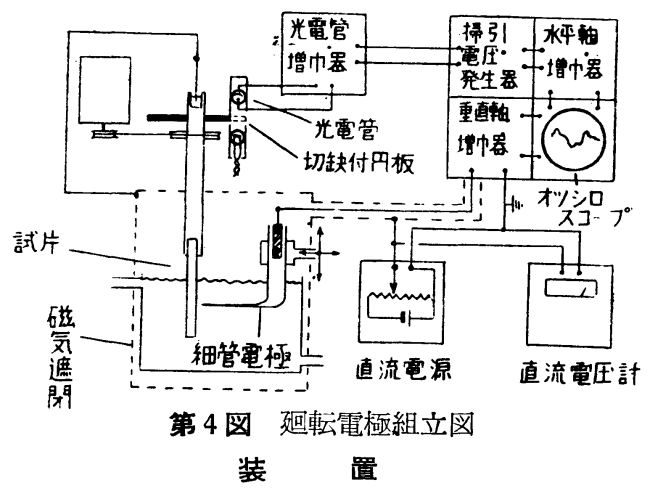

試片は直径 $0.25 \mathrm{in}$, 長さ 3 in の丸棒で, 毎分 1100 回の一定速さでまわる軸につけてある。各試片の中ほど 特よびはしはポリエチンン塗料をぬり，水際や端部の影 響がないようにした。試片を試験せんとする液に浸けて， 長さにして約 1 inの表面が液に触れるようにし，他の部 分は上述の如くに覆ったのである。探針極は $8 \mathrm{~mm} の 0$ $\mathrm{D}$ ガラス管から毛細管に引伸ばし, その部分は $\mathrm{KCl}$ と寒 天の液がつめてある。細くしない部分には $\mathrm{KCl}$ の飽和液 を入れて水銀一甘承電極としてある。探針極全体はマイ クロメーターで支え, 試験片の面から所要の正確な距離 においたり，試片の縱軸に平行に動かしたりできるよう になっている。こうやって試片の全面はそれから所要の 距離にある探針極により走查できる。溶液の容器はガラ ス製で容量 $500 \mathrm{ml}$ であり，底から流入し最上部近くか ら漼流するように作ってある。試片，探針および水槽は すべて磁気的に遮閉されて, 测定回路の感応起電力の影 響がない上うにしてある。

探針電極は直流増巾器の入力側につなぐが，その導線 はシールド端子をもった同心シールド線である。試片は 超転心棒に電父的によく接触するようにしっかりと取附 けられている。超転心棒は磁気的遮閉に水銀溜めの接触 
によってつながれている。遮閉された可変直流電源がシ ールドと直流増巾器の接地された入力端子につながれて いる。この直流電源は, 試片と探針極とよりなる電池の 直流電圧を打消し，それによって比較的小さな交流成分 を歪なしに增巾できるようにするためのものである。こ れは以前に用いた方法，すなわち直流電位の正確な值を 交流成分の測定々同時に行了直流ブロッキング・キャパ シター法よりもすぐれた方法である。

直流増门器の出力は陰極線管の垂直偏向板に入れる。 この管の水平偏向板は直流掃引電圧発生器を組合せ, そ の振動数は試験片の迴転と同期させる。この同期は光電 装置と適当な增巾器とによる。光源とガス入りの小型光 電管を趈転軸の近くにとりつけ，軸につけた円板の短册 孔がその一廻転ごとに光を光電管にあて，かくして摕引 電主発生器に時間を测る胍動をあたえる。

装置の全部を完全に磁気的に遮閉することの必要を強 調することがきわめて大切である。何故ならば回路の抵 抗が大きく，増巾率の大きいことが必要であるからであ る。適当に遮閉することに失敗すると信号と雑点との比 を小さくし，測定した図形に60 サイクルの雑奌が重な ってくる。

廻転電極の装置とは別に試験夜関係の装置がある。液 は小さなポンプによって溜めと電極装置の中の水槽との 閒を常に循環している。水槽から熦れた液はこまかい空 気泡を含む流れのある混気筒中で空気とふれ，それから 溜めへるどる。溜めは䚓拌され，定温に保持されている。 この部分は，試験する環境によってどんな形のものをえ らぼらとる勝手である。

試験夜の比伝導度が $100,000 \mathrm{~m}$ mho 又はそれ以上の ように大さい時には，液が裸線と同ように誘導起電力に 感匛するから全装置を遮閉することが必ず必要であるこ とは注意しなければならぬ。また高抵抗の第二の基準電 極が廻転する試片の代りに用いられたり，試片がこの装 置の電気系統から隔離されているよ5な時には液の伝導 度が $100 \mathrm{~m}$ mho 以上になると上述と同じ注意が必要に なる。

\section{測 定 法}

試片の脱脂，酸洗その他は普通の方法によった。試䮖 液と基準電極は求める温度で平衡状態にあるようにした。

すべての電気装置は測定を始める前に1時聞働かせて その後の変化を防いだ。

用意した試片を迴転軸にとりつけ夜に波ける。探針極 を試片の面から必要な距離に動かす。インヒビタ一の試 験の時刀距離は 0.000 in を用いた。記録は試片を湑け てから 1 分以内に始めた。求めた図形は光学的記録装置 で方眼紙汇記録した。

探針極は記録する度に約 0. . in ずつ試片の面からは
なして，表面の近くの流杞㣻長時間乱され，そのために 普通の状態で表面におこるいかなる反心乱されること がないようにした。

迴転極についての初期の試験では, 図形の最大增门摔 をうるために試片の縱軸に沿ったある位置をえらび，そ の試片についてのその後の図形はすべてその位置でやっ た。これから述べようとするインヒビターについての試 験は記録した各図形に対してそれぞれ最大増巾率をえら んで行った。

\section{図形の解釈}

上に述べたよ5に図形は，探針を試片の表面汇沿って 動かすと試片と基準極とよりなる電池の電位がよ゙う变る かを示するのである。ある円周に沿っての記録された電 位差は局部的な陽極部々陰極部との電位差と，局部芣蝕 電流によるオーム電位とより生じたものである。應蝕電 流は局部電池の電位と電流の流れ道の抵抗との複雑な函 数であるから，記録さ机さ図形と局部窝蝕率とは比較的 な基礎によってのみ一致しうる。

現在までの報告によると、このような制約は闹じ此伝 尊度に㧊いて，ま表面ふら同じ距離での図形享くらべ る時のものである。

後述の比較試験の図形意解釈するためには図形の最少 電位の点を通って引いた横軸と図形との間の面瞔をパラ

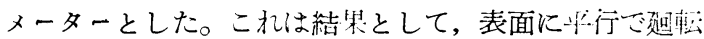
軸に垂直な探針の通路の十面内にある電流のベクトルの 禎分である。

局部陽極および陰極部分は常に变りつつあり，はじめ は一つが，次には他が優勢になっているということは既 に述べた。

このために探針を全问周について位置させて最大面䅡 の図形を生ずるようにすることが必要になる。䩗にの面 禎の単位は任意に $\mathrm{mm}^{2}$ 党とった。

\section{結果の考寒}

一つの試片の縱軸の同じ場所で，それから程々の距離 において得られた代表的图形の様子を第 5 図に示す。こ の図形は局部湯極陰極が完企に定常状態にある時に10分 間隔で一時に記録したものである。各々の図形の最低点 を通る横軸の電位の大さを示してある。おのおのの図形 の初めから終りまでのX軸汇沿っての距離が一つの完全 な円周をなすから，X軸は０９600 に分制される。第 6 図は迴転平面内の一つの半径に沿っての電佗示す。 これらの電位は第 5 図に亦した図形から得られた。各曲 線は上昇傾向を示していることは注意を要する。气して

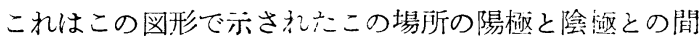
に電䣄の流れがあるのと闰時にこの試片の面上のどこか この場所の近くのより通い陽極からここ企面へ相当な電 流が流れこんでいること衣亦している。 


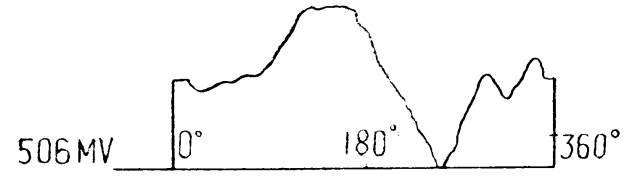

武片丸棒加の距蜼 0010 ”
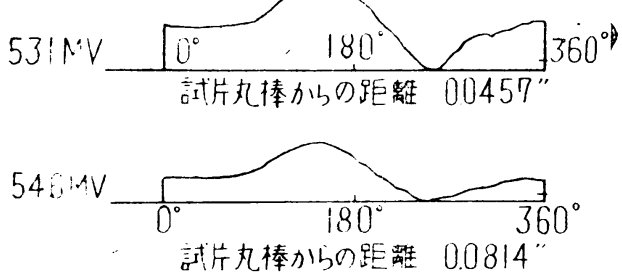

$574 \ldots$

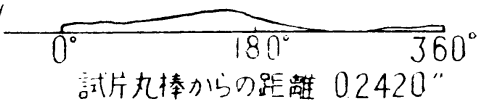

第 5 図

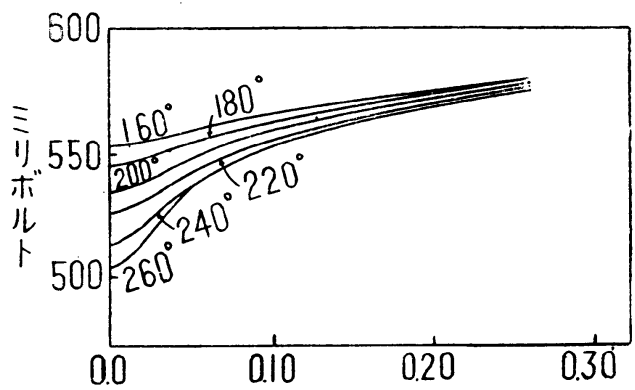

第 6 図一つの半径汇沿っての電位

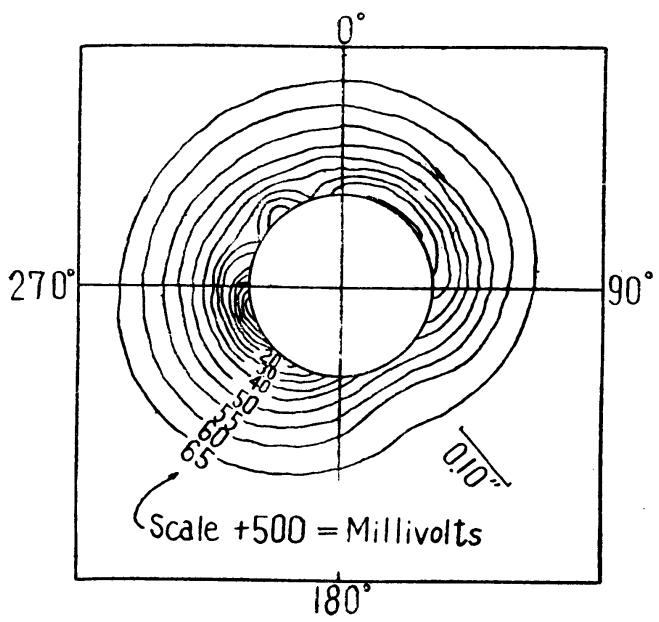

第7図 等電位線

温度 $46^{\circ} \mathrm{c}$, 伝導度 $265 \mathrm{~m} \mathrm{mho,}$ pH 6.2
第 7 図は廻転平面内での電位の等しい点を結んだもの である。これは半径方向の電位を示す第 6 図から作った。 試験片の肉眼観察によると，第 7 図の $260^{\circ}$ の場所のよ うに甚だしく陰極的な所には析出物のないことがわかる。 図形の記録が充分速くできれば，試片の表面から所要の 距離における等電位図を書くことができよう。

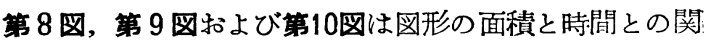
係である。図形は試片の表面から一定の距離で, 四形の 最大面積を得る円周に沿ってやったるのである。これは 異る $\mathrm{pH}$ 值におけるインヒビターの濃度の影響を示して

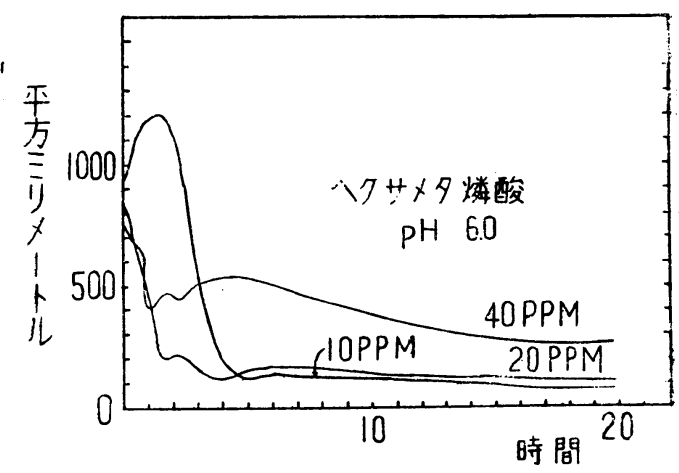

第 8 図

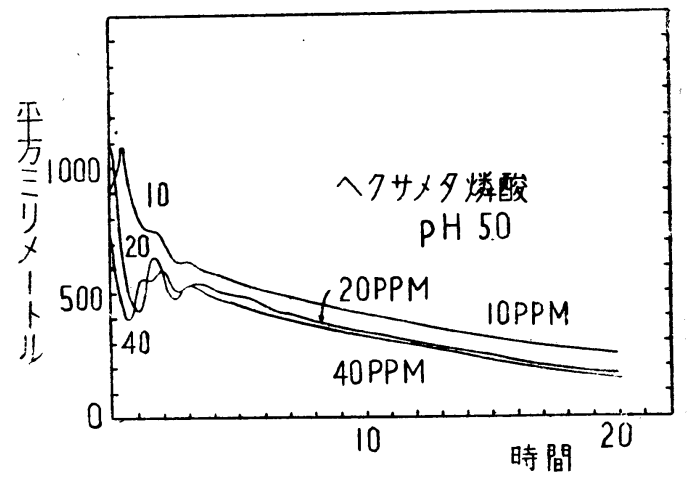

第 9 図

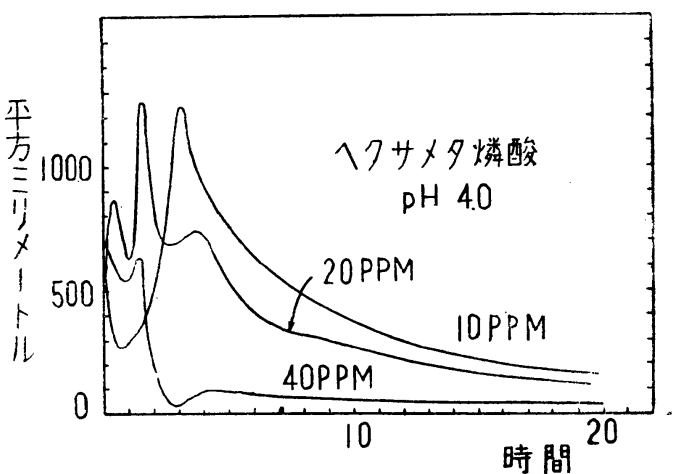

第 10 図 
いる。

試片を観察すると，200 $\mathrm{mm}^{2}$ 以下の図形面積は非常に 低い腐蝕率に相当することがわかった。インヒビタ一の ない液中での試片の図形面積は $1500 \mathrm{~mm}^{2}$ でこれは高い 腐蝕率に相当する。

図形面積と時間との曲線ははじめの $3 \sim 4$ 時間では $50 \mathrm{~mm}^{2}$ 以内の差で再現しうるのが普通である。正確さ はインヒビターの種類によって相当変るらしい。記録し た円周に沿っての電池の平均の電位と, 試片全体の電位 との差，例えばその円周が他の部分にくらべて特に陰極 的（又は陽極的）であるような場合にこれを考えに入れ るのを怠ると，結果の正確さが比較的覀くなることが想 像される。弱い陽極部は陽極的インヒビターによって強 い陽極部より前に受働態化することが図形から推測され る。そこで他の部分より強く陰極的である表面の部分に ついて得られた図形面積は, 強く陽極的な部分から得ら れた図形面積よりも，陽極的インヒビターによって時間 と共に急激に減るであろう。もしこのことが正しければ, これは試験の比較に第二の制約となる。

\section{総括}

これまでの方法によって，優勢な陰極部のなかにも陽 極の存すること，またその逆の場合もあることをたしか めた。また局部電池で陽極から陰極に(またその逆方向 にも）電位の連続的変化のあることをたしかめた。試片 全体の電位の変化は局部陽極と陰極との数の比が変るこ とによってる変ることがわかった。表面に非常に高抵抗 な被膜の存在すること，拈よびその抵抗の大さは溶液の 比抵抗の変化が電位に改ぼす影響をしらべることより求 められとうなことを知った。

そこで上述した趈転電極法は，稀薄電解質口打試片表 面の局部電池作用をしらべる力法として非常に実用的心 ある。現在の状況では得られた数字を直接に重量减少あ るいはそれと似た数字と関係づけることは䒺大な計量を しなければでさない。このような制約があるが，この結 果はインヒビターの作用，いろいろの液の作用および表 面状態等について外の方法で得られた結果と比較しうる しまたもっと多くの知識をあたえるものでもある。し かしこの方法の最も致命的な制約の一つは静止状態の扁 蝕過程をしらべることのできないことである。

\section{文 献}

1) J.B. McAndrew, W.H. Colner \& H.I. Erancis, New way to Detect and Locate Corrosion, Chem. Eng., 59, No.2, 305 (1952) Feb.

2) J.B. McAndrew, W.H. Colner \& H.I. Francis, Rotogenerative Detection of Corrosive Currents, National Advisery Committee tor Aeronauitcs, Technical Note 2523, Nov., 1951.

3) J.K. Rice, A Rev. of Testing Techniques in Cooling Towers, Paper presented at 13th Annual Water Conference, Engineerings Soc. of Western Penn., Oct.21,
1952.

4) J.K. Rice, The Rotating Electrode as a Method of Measurement of Local Cell Action Potentials in Corrosion Testing. Paper presented to the Houston Section, NACE, Houston, Dec. 9, 1952.

\section{討論}

R.S. Y. Yoseph, Chief, Sanitary Engineering, Strategic Air Command, Offutt Air Force Base, Omaha, Neb. : の質間

廻転電極法による测定におよぼす迷走電流の影響の問 題は本著者により極めて上手に报われている。この問題 は私が MIT の水力学研究室で空気覞挥タンク内の溶解 酸素の測定に水銀滴下電極と廻転白金極を用いた装置を 研究していた㭙にも研究題目になった。（MIT Tech. Rep. 3, Public Health Project No. R. G.863, 1951, 論文題目“混気操作打における水中酸素濃度の連続測 定”。 著者, A.T. Ippen, R.S.Y.Yoseph, B. N. Posthill)。装置ができて，実験用混気タンクも完成して からはっきりした理由もないのに変な測定値が出た。 一組のサンプルについての記録計の補正は充召やったの であるから、これは疑問であった。

迷走電流の影響をしらべた結果，装置和よび記淾計を 完全に遮閉することにより容易に良い值が得られること がわかった。そこで混気装置をゴムの台にのせ他の装置 から電気的に絶緣することが必要になった。またすべて の電気的の出力部に電圧安定装羁を用いた。私の意見と しては，ポーラログラフ法による酸素記録計が実用にな るかどうかは迷走電流の影響を消世るか否かにかかって いると考える。溶解酸素の測定が最も重要であるような ある種の混気操作にとってはこのことは侮り難い骨折と なろら。

H. A. Cataldi, Chicago, Ill. : の質問

著者は電気的遮閉のさずかしさを強調し過きて，これ と同様な測定を試みんとする人々の鈆気を挫くようなこ とになりはしまいか。われわれは粒界および熔接の影翼 をしらべるのにこの力法を用いた。電解質はガラス製の ビーカーに入れた。注意すべきことは信号の入る䆃線を 遮閉し，装置の色々の部分を接地することだけであつた。 これと著者の場合との差がどこにあるのか私は疑間に思 う。幸にるわれわれは迷走電流の少ない所にいたのであ るかもしれない。

J.K. Rice : の答

誘導起電力による困奞は電解質の伝導度がますと淢ず る。液の伝導度が数マイクロモ一の程度であると, 液の 容器拈よび導線の遮閉を㛜重にする必要がある。しかし 液の伝導度が数千マイクロモーだと導線はよく遮閧する

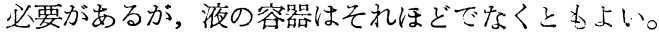

